\title{
New ways of mobility: the birth of ridesharing. A case study from Hungary
}

\author{
Dóra BÁLINT and ANDrÁs TRÓCSÁNYI ${ }^{1}$
}

\begin{abstract}
Recent emerging globalisation and post-industrial development partly driven by IT services influence not only markets, but all other subsystems of the society, too. This revolutionary change has fundamentally transformed our mobility and movements in space. In the era of network society, the idea of shared-use mobility has brought about possibilities in transportation that resulted in the emergence of new groups, directions and destinations. By now this type of alternative transportation has spread among the most developed countries and shows a flourishing example of sharing economy, an internet-based peer-to-peer model, which does not require a top-down service provider. The main focus of the present study is a socio-geographical analysis of how this innovation has spread among Hungarian citizens. Which social groups are the most active users of ridesharing? What geographical endowments or insufficiencies result this way and what are the spatial patterns of transportation? To answer these questions we studied the biggest Hungarian ridematching system 'Oszkár' and its users with the help of questionnaires ( $N=425)$.
\end{abstract}

Keywords: shared-use mobility, ridesharing, sharing economy, Oszkár

\section{Introduction}

As the era of information set in, internet and virtual spaces have fundamentally transformed the everyday life of society, influencing all aspects of our lives including geographic space and mobility. However, the appearance of ridesharing in the $20^{\text {th }}$ century was evoked, instead of internet applications, by other factors. The issue of cost-effectiveness, the high fuel costs and the aims of reducing traffic jams and protecting the environment all played an important role in trying to find solutions to the challenges created by immense motorisation in North America. During the more than half-century period since this highly special combination of individual and community transportation appeared, it has become popular in many places of the world, in a variety of local ways, but could become a global phenomenon only through the immense development of infocommunication.
The objective of the present study is to map the Hungarian spatial patterns of ridesharing, a subtype of community transportation. The authors attempt to investigate the old and new spatial paths drawn up by journeys taking place in the offline geographic space, and to find out about the social background of users. Our research consists of three main parts. Firstly, we have examined the background of users (their age, socio-economic conditions), focusing on possible typical characteristics. Secondly, we have studied their attitudes towards carpooling (motivations, type of carpooling trips), aiming to reveal the most important factors of using this type of transportation. Thirdly, the spatial pattern of ridesharing has been mapped on the basis of completed routes within the framework of the largest Hungarian ridesharing platform ("Oszkár").

The study is done in an empirical way, approaching the answers through a case study, by analysing the most popular destinations

\footnotetext{
${ }^{1}$ Department of Geography, Faculty of Science, University of Pécs, H-7624 Pécs, Ifjúság u. 6.

E-mails: dorabalint29@gmail.com, troand@gamma.ttk.pte.hu.
} 
in a Hungarian ridesharing community, and by analysing the questionnaires completed by its users. We choose this particular community because this rideshare management system has several hundred thousand registered users and covers the entire Hungarian spectrum of users both vertically and horizontally. Among various shared-use mobility types, 'Uber' is the most well-known sharing transportation start-up, providing shorter, multi-directional routes of one or two kilometres rather than longer journeys, but Uber is present only in the capital. Thus, it is not suitable for a country-level analysis.

\section{Research background}

\section{Context of the research: the rise of the sharing} economy

Sharing economy (also called on-demand, access-based or collaborative economy) is an umbrella term describing emerging economic-technological systems, which first appeared in the 2000s. It is not a brand new phenomenon, sharing being an old, culturally learned behaviour (BELK, R. 2007), but recently it has been fuelled by developments in information and communication technologies (ICT) (Hamari, J. et al. 2015). Due to this revolution, new technology-driven platforms make possible individuals to connect with each other peer-to-peer and share their underused tangible (flats, cars, goods etc.) and intangible (time, skills etc.) assets when others need or can make use of them (on-demand economy). The main platform where transactions occur is Web 2.0. With the help of global social media use and the worldwide proliferation of smart phones, demand and supply can find each other easier and quicker, often in real-time without centralised organizations. Therefore, one of the most important factors is the bigger scale the large number of people and societies who have internet access can participate in this model. Consumption is also transformed; access has become more important than owner- ship in the concept of the access-based economy (BARDHI, F. and EскHARDT, G. 2012, 881). The third often used term connected to the sharing economy is collaborative consumption "where people coordinate the acquisition and distribution of a resource for a fee or other compensation" (BELK, R. 2014, 1597).

Obviously, these changes are part of a larger shift facilitated by ICT, which represents the evolution of the network society. According to Manuel Castells (2000) networks restructure the morphology of our societies, while Jan van Dijk (2012) highlights that in the new, network society people increasingly organise their relationships in media networks, which might gradually replace or complement the traditional social networks of face-to-face communication.

The sharing economy has caused fundamental changes in society (including mobility) and has raised a huge number of challenges. New paradigms always cause tensions between the old type of actors, in this case between public sector leaders and new types of organisations and their users, supporters. Therefore, the sharing economy is also referred to as a disruptive innovation (GUTTENTAG, D. 2015), using the concept of CHRISTENSEN, C.M. (1997). In our globalised and interconnected world, sharing economy actors have grown to become influential organisations. The largest ones, Airbnb and Uber, have appeared in many countries of the world (Uber in 471 cities in 70 countries in June, 2016 www.uber.com) raising a number of challenges and conflicts, regulatory and legal issues as in the case of Oszkár, which we present here in details. These conflicts are embodied in "offline spaces" like the streets of urban areas from Rio de Janeiro to London or even to Budapest where there are continuous protests against Uber, the urban short-distance ridesourcing service. Ironically, popular sharing economy start-ups have changed the image of the sharing economy itself, as their activities are less about creating great values like building social capital or reducing environmental pollution, but in the first place, about making huge profits. They have turned from altruistic 
efforts to profitable business ventures and as such they have become global players. The best known example of this phenomenon is probably the accommodation renting start-up Airbnb, which was valued at around 20 billion USD in 2015 (skift.com). Only traditional hotel brands like Marriott or Hilton have a higher value.

\section{Sharing economy in transportation: shared-use} mobility

With the use of the sharing economy, a wide range of vehicles, routes and distances can be shared among individuals. Services include different transportation means and sources from bicycles car sharing, ride-sourcing, ridesharing, to taxis and limos and shuttle services. Geographical differences develop local varieties of global ideas and services including short-term ride-sourcing in US metros, daily commuting sharing (carpooling) in South Africa, and long-distance guest labourers sharing travel between Hungary and Germany. Shared-use mobility and alternative ways of transportation are not new concepts in motorized societies either: the most obvious example is traditional public transport system. This operates on a similar principle, but probably the most important difference between public transportation and shared-use mobility is flexibility.

Public transportation is often organized in a top-down, fixed routes and price models; however, more flexible services have been available in less-developed countries in the forms of urban and rural shuttles, and minibus taxis. Shared mobility is more efficient than individual travelling because it can reduce traffic congestion and pollution, also it allows people to travel together with other people in one vehicle any distance from within the urban environment to transcontinental routes. Better effectiveness results from the fact that already existing, utilised capacities are used more efficiently, but the popularity of this phenomenon also encourages people to launch their own businesses that rely precisely on this ever increasing customer base. In this case, it is not already existing capacities that are utilised more rationally, but new capacities are included in the particular service. Shared mobility is not only more efficient, but it is also more flexible, as it can react to demand changes rapidly. Lacking a fixed time schedule, shared mobility requires a different kind of attitude from both passengers and drivers. On the other hand, this new form of mobility has disadvantages such as security problems, lack of reliability and taxation issues.

In this study we focus on a popular shared transport mobility service in Hungary, a technology-facilitated long-distance ridesharing. This type of shared travel is defined as "two or more trips are executed simultaneously, in a single vehicle" (Morency, C. 2007, 240). It is important to distinguish between the two most popular concepts in shared-use transportation, i.e. car vs. ridesharing. The main difference between car- and ridesharing is the object being shared. In the first case, it is a tangible asset, the vehicle, usually a car, while in the second case it is a traveller's ride that is shared, even if the common mode of transport is an automobile. When a ride is shared, a small group of people (at least two people) travel in one vehicle (car or shuttle) at the same time, while in car-sharing people use the same car one after the other.

Both types had existed much earlier than the spread of Web 2.0. Traditional forms of ridesharing (car-pooling and van-pooling) were promoted as early as WW2 because of oil and rubber shortages and also later in the 1970s employers started supporting the creation of carpools, which was a rather a topdown system (Furuhata, M. et al. 2013). On the other hand, bottom-up processes also exists, and are motivated by parking conditions, according to user focused studies (CsonkA, B. and Csiszér, Cs. 2016). Carpooling is mostly used among commuters who share a privately owned car so they increase car occupancy potential and decrease the costs of regular travelling and traffic congestion. HOV (high occupancy vehicle) lanes in countries like the US or New Zealand were also created to sup- 
port carpooling. Car sharing first appeared in Europe around 2000, but it has become especially popular with the introduction of peerto-peer car-sharing systems in 2010, and now it is present on all continents. The largest car-sharing company is Zipcar, which can be found in most countries of Europe and North America, but some automobile manufacturers (e.g. General Motors, Mercedes) have also started participating in this developing sector (BARDHi, F. and EcKHARDT, G. 2012).

Car-sharing services provide their members access to automobiles for shorter distances, usually for local trips, therefore they do not have to pay the constant costs (insurances, taxes, depreciation) of owning a car (BARDHI, F. and ECKHARDT, G. 2012). Participants have to pay a reasonable monthly or yearly fee for the service, must have a valid driving licence and pass a background check, which includes their driving history. The advantages of commercial car sharing is that members do not have to pay the high costs associated with maintaining a car but they can enjoy the flexibility a car (pool) can provide (BELK, R. 2013).

Most ride-sharing start-ups that have emerged in Hungary since the 2000s (e.g. BlaBlacar, Oszkár) match drivers offering vacant seats for long-distance drives with passengers travelling to the same destination through applications. Companies typically limit the amount drivers can charge in order to exclude profit oriented drivers.

\section{Oszkár, a Hungarian start-up enterprise in ride-sharing}

In this study we investigated the rides of Oszkár, the largest and most popular long-distance ride-matching company in Hungary, with nearly 320,000 registered users (that is 3.23\% of the Hungarian population) and nearly 100,000 active users. ${ }^{2}$ Oszkár is a typical start-up related with online space and not operated as

\footnotetext{
${ }^{2}$ Definition of an active user according to Attila Prácser (Co-founder and Managing Director, Oszkár.com): at least one journey over three months.
}

a profit-oriented organization. Its number of users, history, operation and the variety of the available routes make Oszkár worth studying from a geographic point of view.

In the Oszkár ridesharing system drivers offer vacant seats in their vehicles on their routes, as a way of reducing costs and in many times to reduce boredom. Passengers can reserve a seat through the web page where they obtain information - after their registration - and read comments about the driver, the car, possible fellow passengers, and can find out more about the journey (e.g. smoking, travelling with pets, etc). The passenger can join the ride during the agreed time in a predetermined location (normally in a parking lot), and the journey commences, leading to the destination(s).

The rides are usually unidirectional, return journeys with the same drivers not being typical. According to GYüRüs, M. et al. (2008) there are three main types of routes. These are simple one-way trips, routes repeating aperiodically the same path (holidays trips), and routes repeating periodically the same path (daily commuting trips).

The trust between passengers and drivers is ensured by the service provider through a reviewing system, a vital element for all kinds of community services operating in online space, since while on the move, users entrust strangers with their safety. The trust ensured by evaluations from the community counterbalances for the official, legal guarantees missing in the case of non-professional drivers (e.g. professional driving licence, more frequent technical inspections and medical investigations, compulsory technical parameters). The studied ridesharing system does not have fixed prices, but there is an upper price limit in the system (18 HUF per $\mathrm{km}$ - approx. 5 Eurocents per $\mathrm{km}$ - in 2015), in order to avoid abuse and to keep prices lower than official tariffs (oszkár.com).

In the case of services based on sharing, an often discussed issue is regulation and taxpaying by users. Because ridesharing and other similar platforms developed too fast for legislation to be able to follow them, 
the majority of them are still part of the to grey economy. Non-commercial ridesharing with the purpose of only sharing the costs of a journey is not subject to taxation according to Hungarian law, but it is also possible to do a profit-oriented passenger transport business through Oszkár, in which case a National Tax and Customs Administration registration (taxation number) and launching a private enterprise are required. In this case, certain regulations of Oszkár (e.g. upper price limits) do not apply to commercial drivers (oszkár.com).

\section{Methods}

In this study we used quantitative methods to justify our hypotheses, which can be divided into two major categories. The first includes the questions that look at the profiles, social and societal backgrounds of Hungarian ridesharers, which we acquired through an online questionnaire $(\mathrm{N}=425)$. The online survey was shared with the users on the web page and the Facebook page of Oszkár, the ridesharing platform with the highest number of users in Hungary. Accordingly, the sample is not random and not representative; the only precondition of being included in the sample was that the answerer had to have used a ridesharing service at least once, either as a driver or as a passenger. Through the online distribution of the questionnaire, not only the registered users of Oszkár could become included in the sample, but also the users of any other type of organised ridesharing service or platform who accessed the questionnaire either through the webpage or through Facebook page (e.g. BlaBlacar or shared rides organised through Facebook-groups).

The anonymous questionnaire was active for a total of five days between 19-23 August 2015 , containing both open and closed questions, asking about the social background and ridesharing habits of travellers. The choice of the time of sampling was a consequence of research scheduling, thus the obtained answers contained seasonal char- acteristics too, which were eliminated by analysing other types of data as well. The questionnaires were completed by residents of a total of 140 different settlements, most of them being from Budapest (88 individuals), Pécs (39) and Szeged (28). According to our hypothesis, the majority of travellers are mostly young people (between age 20 and 40), since it is these people who most actively use community websites, and have the greatest level of mobility among all social groups ${ }^{3}$. Besides this, due to the price sensitivity of most Hungarians (TIBORI, T. 2010), we assume that the cost of travelling has an important role in the growing popularity of ridesharing, in the choice of how to travel, and in determining who is using them.

In the second part of the research we focused on the possible offline effects of shareduse mobility, appearing in the geographic space, whether or not this type of mobility creates new spatial relations in Hungary. Does it facilitate an increased mobility for members of the society, or does it only have a complementary role? To answer these questions, we investigated, in addition to using questionnaire data, the most popular routes and destinations, for which data were obtained from the Oszkár ridesharing system. The database included indicators (directions and prices) of the 50 most popular routes in the study period, adding more details besides the questionnaire to the picture about the spatial structure of Hungarian ridesharing. The database contained the average costs of the routes (locations of departure and destination) in altogether four time periods (two summer, one autumn and one winter week), making it possible for us to make comparisons with the costs of other mobility types. The four different sampling times (Table 1) allowed us to reveal seasonal differences, and helped us interpret and counterbalance the results of our questionnaire survey.

The routes in the database were analysed using simple calculations in Excel (adding

\footnotetext{
${ }^{3}$ http://www.slideshare.net/slideshow/embed_ code/31818007.
} 
Table 1. Analysed routes and time periods

\begin{tabular}{l|l}
\hline \multicolumn{1}{c|}{ Date } & \multicolumn{1}{c}{ Attributes } \\
\hline 22-28 September 2014 & \\
8-14 December 2014 & 50 most popular routes \\
29 June-5 July 2015 & and their average prices \\
27 July-2 August 2015 & \\
\hline
\end{tabular}

passenger numbers in same destinations, trip calculations per thousand inhabitants) during which they were separated based on departure and destination locations. Thus, it became possible to analyse the greatest source and receiving settlements, and observe any possible spatial paths or patterns being formed.

We collected public transport prices from the official website of Menetrendek.hu ${ }^{4}$ in August 2015, which also includes bus and train ticket prices. After that, we calculated average prices for bus, train and also for ridesharing for the same routes.

We conducted an online questionnaire, which was available at www.oszkar.com Facebook page between 19/08/2015 and 23/08/2015. It contained 26 questions in three parts:

- Open questions about ridesharing habits (how do they use it? How far they travel? How often they travel?)

- General background data (age, sex, residence, highest education level) - multiplechoice questions.

- Open questions about their motivations (Why do they use it?)

The routes of the various time periods were then mapped, providing an opportunity to investigate the most important transportation geographic corridors, too.

\section{Results}

Social background and age structure of Oszkár users based on questionnaire results

Nearly two-thirds of the questionnaire participants said they had been involved in ride-

\footnotetext{
${ }^{4}$ A collective timetable for all inter-city public transport in Hungary.
}

sharing as passengers (62\%), 22 percent as drivers, and 16 percent had been involved in both. The latter suggests that ridesharing, in addition to being a necessity is possibly also a sort of community involvement means or even a habit. Regarding the gender distribution of participants, the representation of women was somewhat higher (54\%) than that of men (46\%), which can be explained by the higher willingness of females to complete questionnaires. However, if the types of ridesharing are analysed among sexes, a different picture emerges. A substantial dominance of women is present regarding the passenger role ( $70 \%$ females, 30\% males), while gender distribution is just the other way round in the case of drivers ( $16 \%$ females, $84 \%$ males).

The primary reason for this is probably that the proportion of female drivers in Hungary is still smaller than that of males ( $40 \%$ among people possessing a category ' $\mathrm{B}$ ' driving licence $-\mathrm{ksh} . \mathrm{hu}$ ), and this difference is further distorted by the fact that women probably are more uneasy about taking the higher (safety) risk of being a driver, and passengers are evaluated much less frequently than drivers. Even in an international comparison, female drivers are more typically involved in household-based/internal ridesharing or fampools, or the pooling of children's schoolmates and friends (VAnoutrive, T. et al. 2012). Another factor contributing to this result is that regular automobile driving and mobility is more typical for males than for females and even the official or semi-official journeys tend to be shared by predominantly male drivers earning a living partly from driving.

The distribution of people having returned the questionnaire on the basis of highest level of education shows that people with higher education qualifications are over-represented in the sample. Among of the people answering the questionnaire, 58 percent possessed some type of university or college degree, while this rate among the entire population is only 14 percent according to the 2011 census (ksh.hu). In our opinion this is determined by several factors acting together. The rate of using sharing-based techniques and services 
is considerably higher among young people and those with higher qualifications, and also, general mobility is more typical for highly educated people as well as young adults. Based on age data, it becomes clear that these forms of ridesharing in Hungary are used mostly by young people having normally completed their higher education studies.

The first figure (Figure 1) shows the age distribution of users, i.e. drivers and passengers. In both categories this type of mobility is most popular among people in their late 20s (between 26-30 years of age), them being the most frequent users of Oszkár. In the case of passengers, there is another peak, namely at the middleaged group (people between 41-45 years).

Based on the survey the ride-sharers can be grouped into two categories. On the one hand there are the young working people belonging to the young $\mathrm{X}$ (millennial) or Z (digital native) generations having completed their higher education studies and thus having no student travel discount (70\% of people completing the questionnaires did not have any kind of travel discount), who already belong to the children of information society and use community media as an organic part of their life. For them, it is more natural to organise part of their geographic space use in virtual space. On the other hand, there is the group of middle-aged people in their 40s who, besides quickly adopting the innovation, have some other type of motivation too, such as living in out-of-the-way settlements with weak public transportation connections, thus for them fast and relatively cheap ridesharing means an alternative to other, organised forms of mobility. From the data analysis it also appears that this group also includes the occasional ride-sharers for whom Oszkár means an innovative and flexible solution for reaching a destination every now and then. Relating to this, the following section investigates how much ridesharing functions as a competition to other modes of transportation.

\section{Price sensitivity and complementarity}

To analyse price sensitivity, we have compared the prices of the 50 most popular routes in a chosen summer time, with other possible travel options. The average prices of ridesharing were obtained from a source specified by Oszkár, while the fares of bus and train journeys were taken from the public tariff table of the service providers, and all these were then arranged in a database. The reason for choosing the summer time frame was that we wanted the best match with the environment of our online questionnaire, most importantly the seasonally changing prices.

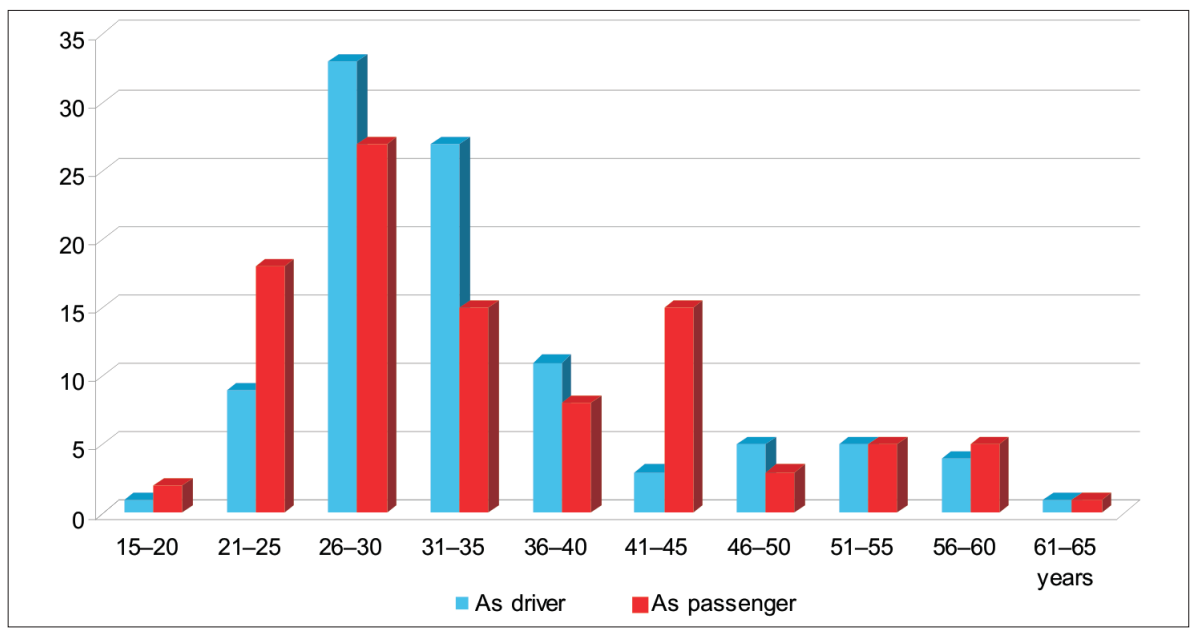

Fig. 1. Age distribution of passengers and drivers in percent. Source: Compiled by the authors based on Oszkár data 
According to the results, the cheapest way of travel out of the three possible types was, regarding full-price fares, ridesharing (Figure 2). The average prices of ridesharing ranged around 3,000 HUF (approx. 10 EUR), followed by the bus fare with 4,500 HUF, and train tickets with 4,700 HUF.

This ranking, however, will be quite different if the popular reduced fares (e.g. student discounts) are taken as a basis, in which case ridesharing will be the most expensive alternative among the three. In other words, ridesharing is positioned by its tariffs in between full-price and reduced-fare interurban public transport prices. This is why Oszkár is used most widely as passengers by the age group of 26-30 years, whereas reduced-fare public transport is the cheaper alternative for the most frequent commuter, price-sensitive group of university students. Thus, from the analysis of routes it appears that cost is the primary factor among the different motivations. This is supported also by the next chart (Figure 3), which shows the various transportation modes the participants had used on similar routes before becoming involved in ridesharing.

It was found that most people chose this new type of community-based mobility as a substitute for travelling by train. Besides the high-price factor (full-price tickets) in the case of travelling by train, another important element of motivation is the rigidity of the railway system, and, in the case of certain destinations, insufficient access.

Based on the answers to the questionnaire (Figure 3) it is concluded that only a few journeys were induced merely by the newly

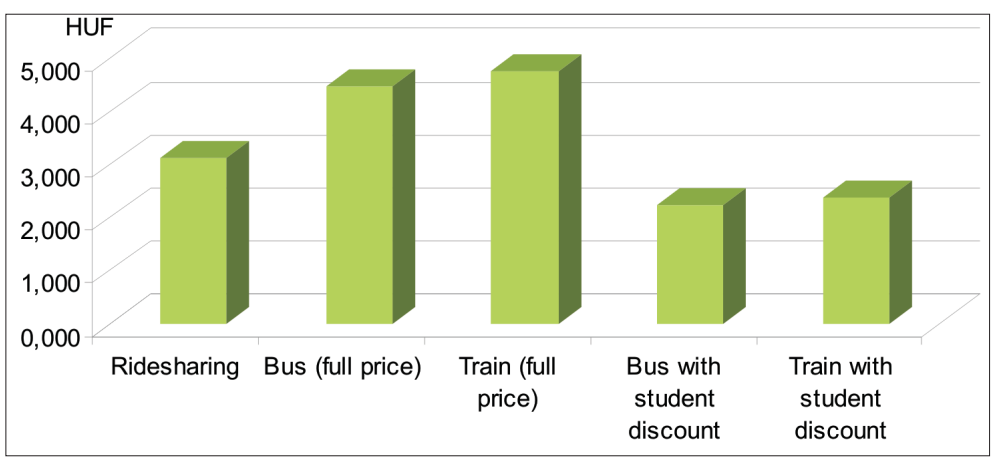

Fig. 2. Types of transportation and their average prices. Source: Compiled by the authors based on oszkar.com, menetrendek.hu

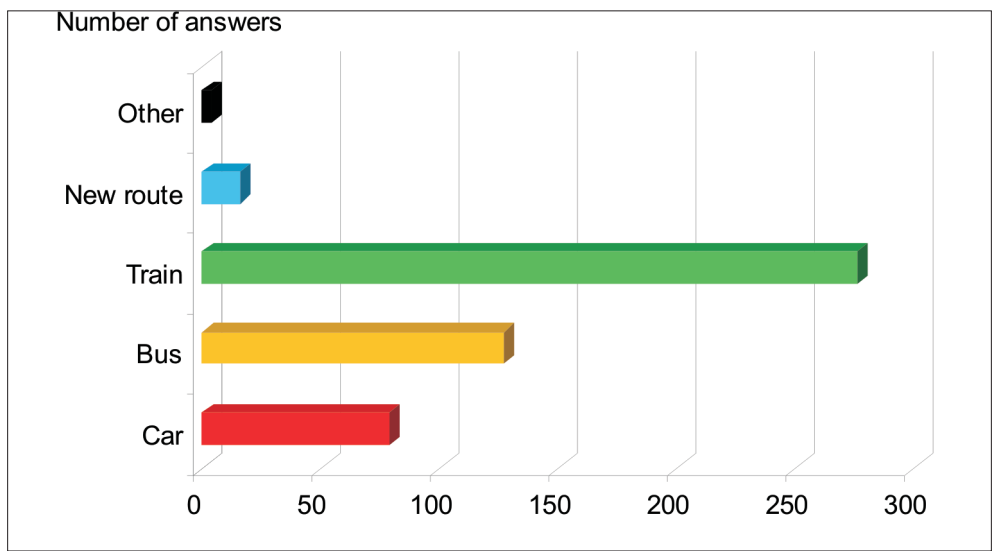

Fig. 3. Popularity of transport modes before using ride-share $(\mathrm{N}=425$; multiple choices) 
appearing possibility of ridesharing, but instead, the majority of passengers would have travelled on those particular routes anyway, without the availability of ridesharing. This means that journeys having taken place in the studied ridesharing system do not generate significant new spatial paths in the geographic space, but instead they played a complementary role. This complementarity, too, indicates that the mobility routes in the Hungarian spatial structure have not been completed (in such a short time) with new paths, since the market is yet too small for that to happen. In the literature there are few large-scale studies fully answering this question. However, when Airbnb, the hotel industry actor newly emerging in sharingeconomy was analysed, it was found that although it does draw away clients from certain segments of the market, it does yet indicate a threat to the whole hotel market (Zervas, G. et al. 2015).

\section{Source and destination settlements}

If the routes are separated according to departures and destinations (Table 2), and these are summarised on the basis of settlements, the geographic aspects of ride-sharing can be analysed. Regarding both arrivals (destinations) and departures, Hungarian cities dominate. Quite obviously, the most popular destination is the capital, followed by regional centres, with only the seasonally favoured settlements being able to line up in this listing.

The predominantly unipolar character of the Hungarian settlement network, along with the cultural-economic significance of Budapest is reflected well in the spatial structure of ridesharing, too. On the other hand, an essential precondition for the penetration of sharing-economy is the presence of a critical mass (Botsman, R. and Rogers, R. 2011; Chan, N.D. and SHAHeEn, S.A. 2012), which is another factor justifying the hegemony of the capital city. Regarding the possible routes, Budapest stands out prominently, having a marked positive balance. Values obtained for the capital city stand far above those of the second-ranking entities in both dimensions. However, while this difference is eightfold with respect to destinations (arrivals), i.e. correlates with population sizes, it is only twofold in the case of source (departure) settlements. In other words, ridesharing is used by its passengers mostly for reaching the capital, particularly from areas and in times that offer no other alternatives.

The ranking of ride-sharing destination and departure popularity correlates with the general settlement hierarchy, except for occasional cases of a festival (Sopron), an event (Kapolcs), and certain seasonally attractive settlements (e.g. on the coastline of Lake Balaton) with poor accessibility from certain departure points. Interestingly, the destinations abroad for workers and/or big cities popular among Hungarian employees (Munich, Vienna, Ulm, Passau, London, Stuttgart, Regensburg, Zurich, Nuremberg) have relatively high rankings on the list, with a combined value similar to that of a larger Hungarian city on its own.

Regarding source settlements, the list includes pretty much the same settlements, but the ranking is different in several positions. Evidently, the seasonally popular Hungarian settlements disappear from among the big sources. Foreign departure locations are almost unchanged, although their ranking is somewhat different. This balance is probably related to the size of the particular settlements, and the availability of alternative public transport. Assuming that the ridesharing traveller does not stay at the destination (forever), the data confirms that Oszkár provides a complementary alternative beyond public transport in an era when travellers expect the greatest time efficiency along any route.

Having looked at the absolute numbers, we then focused on where ridesharing was the most popular, relative to population sizes of the communities, and found the following pattern (Figure 4.).

Clearly the highest figures came from for regional centres where, in accordance with 
Table 2. Numbers of passengers per settlement (arrivals and departures)*

\begin{tabular}{|c|c|c|c|c|}
\hline Rankings & $\begin{array}{l}\text { Settlements } \\
\text { (arrivals) }\end{array}$ & $\begin{array}{l}\text { Number of } \\
\text { passengers }\end{array}$ & $\begin{array}{c}\text { Settlements } \\
\text { (departures) }\end{array}$ & $\begin{array}{l}\text { Number of } \\
\text { passengers }\end{array}$ \\
\hline 1 & Budapest & 16,420 & Budapest & 9,175 \\
\hline 2 & Debrecen & 2,012 & Szeged & 4,293 \\
\hline 3 & Pécs & 1,472 & Miskolc & 3,819 \\
\hline 4 & Miskolc & 1,198 & Pécs & 3,271 \\
\hline 5 & Nyíregyháza & 1,060 & Nyíregyháza & 1,158 \\
\hline 6 & Sopron & 816 & Debrecen & 772 \\
\hline 7 & Siófok & 629 & Győr & 673 \\
\hline 8 & Győr & 303 & Kecskemét & 231 \\
\hline 9 & Veszprém & 229 & Vienna (Austria) & 227 \\
\hline 10 & Szeged & 219 & Nagykanizsa & 187 \\
\hline 11 & Eger & 218 & Szombathely & 157 \\
\hline 12 & Munich (Germany) & 180 & Hajdúböszörmény & 148 \\
\hline 13 & Balatonfüred & 175 & Baja & 136 \\
\hline 14 & Kapolcs & 157 & Zalaegerszeg & 128 \\
\hline 15 & Baja & 156 & Székesfehérvár & 106 \\
\hline 16 & Kaposvár & 146 & Kaposvár & 103 \\
\hline 17 & Vienna (Austria) & 145 & Veszprém & 79 \\
\hline 18 & Kecskemét & 118 & Stuttgart (Germany) & 69 \\
\hline 19 & Keszthely & 110 & Keszthely & 65 \\
\hline 20 & Mátészalka & 109 & Mátészalka & 65 \\
\hline 21 & Nagykanizsa & 85 & London (England) & 63 \\
\hline 22 & Kazincbarcika & 81 & Hódmezővásárhely & 61 \\
\hline 23 & Balatonlelle & 77 & Makó & 59 \\
\hline 24 & Balatonboglár & 73 & Hajdúnánás & 58 \\
\hline 25 & Békéscsaba & 55 & Munich (Germany) & 56 \\
\hline 26 & Fonyód & 54 & Szekszárd & 55 \\
\hline 27 & Szekszárd & 51 & Tapolca & 48 \\
\hline 28 & Zamárdi & 50 & Békéscsaba & 47 \\
\hline 29 & Tiszaújváros & 46 & Sopron & 47 \\
\hline 30 & Révfülöp & 45 & Eger & 42 \\
\hline 31 & Makó & 43 & Tiszaújváros & 37 \\
\hline 32 & Salgótarján & 40 & Kisvárda & 35 \\
\hline 33 & Kisvárda & 39 & Nuremberg (Germany) & 35 \\
\hline 34 & Ulm (Austria) & 35 & Polgár & 35 \\
\hline 35 & Zalegerszeg & 33 & Mannheim (Germany) & 25 \\
\hline 36 & Passau (Germany) & 31 & Salgótarján & 25 \\
\hline 37 & London (England) & 30 & Cologne (Germany) & 23 \\
\hline 38 & Stuttgart (Germany) & 28 & Balatonalmádi & 21 \\
\hline 39 & Szentes & 24 & Linz (Austria) & 21 \\
\hline 40 & Balatonfenyves & 23 & Regensburg (Germany) & 19 \\
\hline 41 & Mohács & 21 & Siófok & 17 \\
\hline 42 & Csongrád & 19 & Mohács & 13 \\
\hline 43 & Regensburg (Germany) & 18 & Frankfurt (Germany) & 11 \\
\hline 44 & Zurich (Switzerland) & 18 & Passau (Germany) & 11 \\
\hline 45 & Nuremberg (Germany) & 16 & Paks & 10 \\
\hline 46 & Székesfehérvár & 16 & Szolnok & 10 \\
\hline 47 & Balatonalmádi & 11 & - & - \\
\hline
\end{tabular}

*Only settlements with figures greater than 9 are included in the tables. Source: www.oszkar.com

those written above, ride-sharing had become a popular way of reaching the capital. This statement is supported by the fact that the relative figures seem to be inversely cor- related with the economic development of regional centres located at about equal distances from the capital. The less developed centres (e.g. Miskolc and Pécs) have higher 


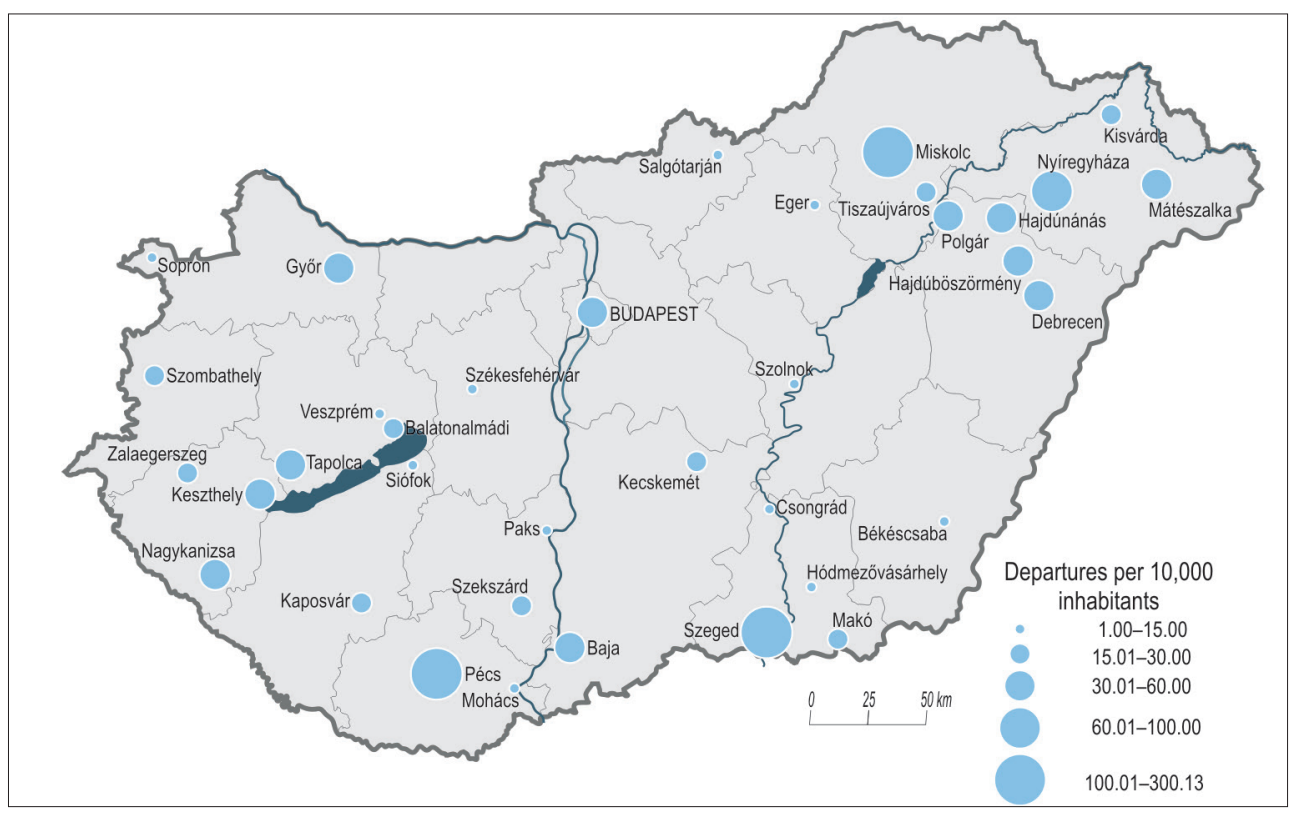

Fig. 4. All departures per 10,000 inhabitants by main cities. Source: Compiled by the authors based on Oszkár data

indicators, while the more developed Győr and Debrecen have smaller figures. The map shows a strong NE Hungarian concentration too, which has multiple reasons. One explanation can be the poor public transportation accessibility of the region, and on the other hand, due to its weaker developmental indicators, it traditionally functions as one of the capital's commuter attraction zones. In such a case, ridesharing is a significant competitor to public transportation, especially the railway, because in addition to being cheaper, ridesharing also substantially shortens travel time, which factors can strongly influence people's choices in long-distance commuting.

When the geographic distances of domestic trips are analysed, a $100 \mathrm{~km}$ distance is the critical threshold in ridesharing mobility. The majority of journeys fall into the 150-200 $\mathrm{km}$ range; thus, in view of Hungary's size and spatial structure, it can be suggested that ridesharing first of all assists interregional transportation connections (Figure 5). Beyond the particular conditions of the country's spatial structure, another reason why great- er distances dominate in ridesharing is that, according to literature, when vacant seats are shared with others, and passengers are picked up, the necessary detours make this shared type of mobility less suitable for travelling short distances (FERGUSON, E. 1997).

According to the results of the questionnaire, 85 percent of those submitting their answers used ridesharing only on domestic routes, despite the fact that with longer distances even greater savings can be realised. Possibly, the critical mass in the adequate routes and ridesharing offers does not yet exist to allow ridesharing to gain considerable ground as an international travel option.

\section{Seasonality and flexibility}

When analysing the seasonality of routes from the perspective of distance, no significant differences are found (Figure 6). The average distances discussed above appear here too. There is some difference in the numbers of routes longer than $300 \mathrm{~km}$ : they are more 


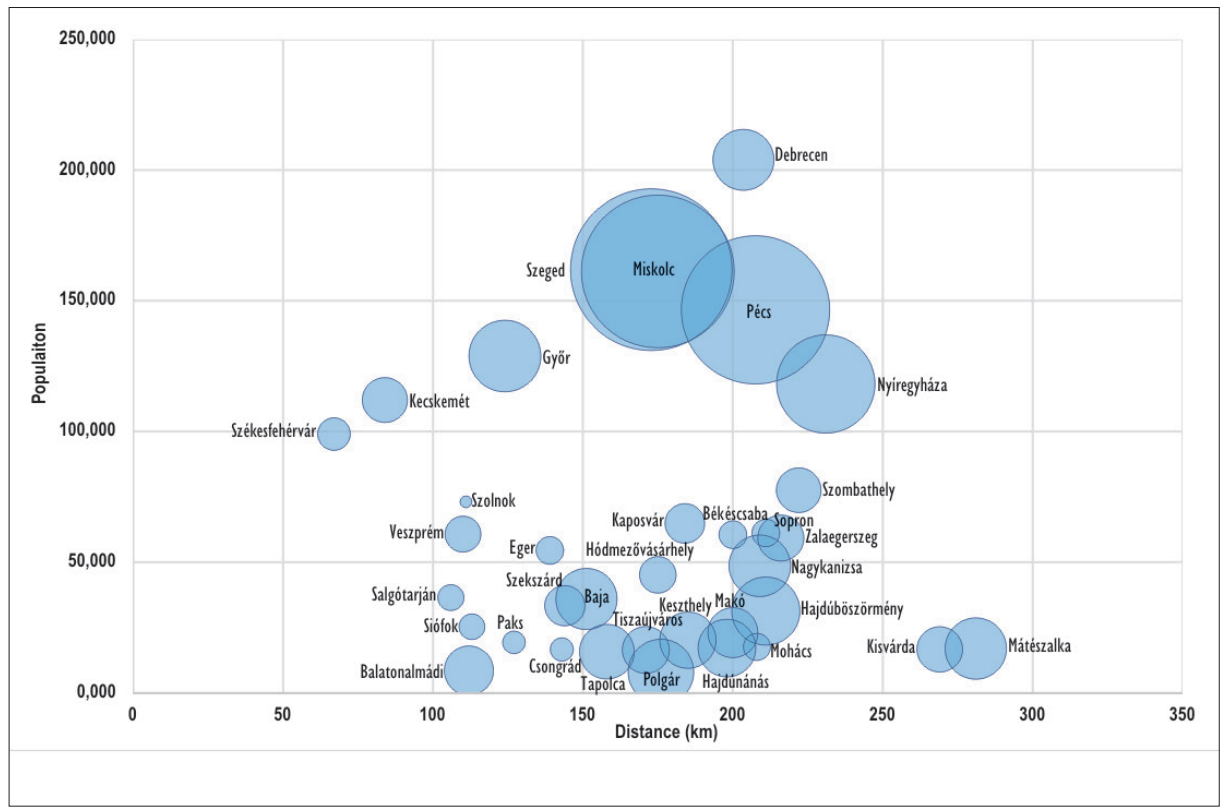

Fig. 5. Domestic departures per settlement size and distance (excluding Budapest). Source: Compiled by the authors based on Oszkár data

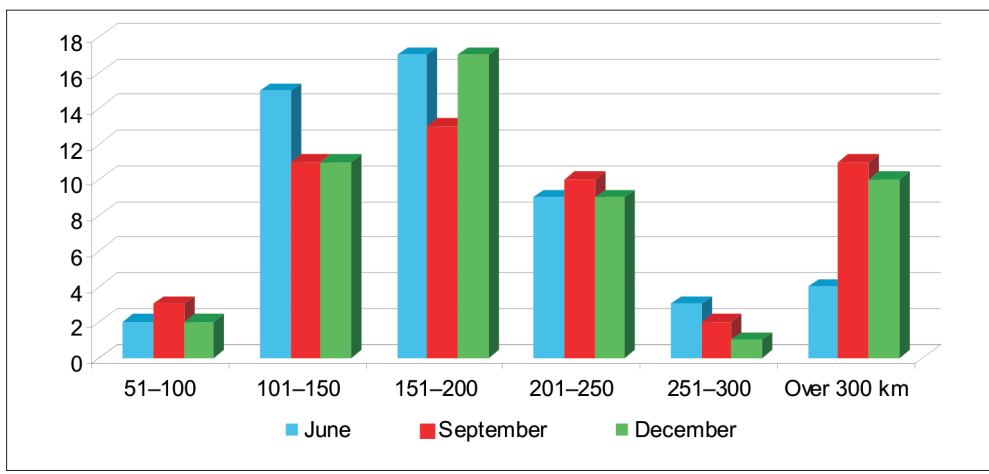

Fig. 6. Number of routes per seasons. Source: Compiled by the authors based on Oszkár data

frequent in autumn and winter, which indicates that Oszkár journeys abroad are made up mostly of commuting of Hungarian guest labourers. As mentioned above, the international numbers are still quite low, which can be explained, besides the absence of the critical mass, by the presence of shuttle services for foreign workers that are much more flexible than public transport in general.
Looking at the spatial element the centralised travel pattern is present in the routes analysed, with only a few transversal paths connecting the towns and cities around the country. As we have found, a route between say Debrecen and Pécs, even if it is present among the offered or demanded routes, disappears from statistics because the majority of the drivers advertise their destinations via the capital too, in order 
to maximise their business and to cut down on travel time. These statements are supported by Figures 7 and 8, which showing the routes during summer and winter period.

Occasional journeys are more typical in the summer season, such as ones leading to Sopron, the location of the Volt Festival, from Budapest and other significant university towns around the country such as Pécs and Szeged. Routes to and from Budapest and settlements along the coast of Lake Balaton are also more pronounced in the summer season. If the two maps are compared, it appears that journeys to the two Germanspeaking regions (southern Germany and Austria) are more typical in the winter period, but London, the farthest destination, is present in both. Shorter routes appear in early December - Szeged-Baja, DebrecenNyíregyháza, Debrecen-Miskolc - the more common routes of domestic commuters. Based on questionnaire data, the latter represent the minority, since 60 percent of the people answering the questions choose ridesharing only occasionally, in connection with some particular event (e.g. vacation or visits to relatives), and only 40 percent use it regularly (on a daily, weekly or monthly basis). This indicates the flexibility of ridesharing, that it can adapt rapidly to changes in what users require, and that it is more flexible than the other types of transport, capable of reacting fast to major events. As such, sometimes smaller settlements can have strikingly high shared mobility values (e.g. Kapolcs).

\section{Conclusions}

Ride-sharing is a popular form of sharingmobility, whose wide spread distribution was assisted by the internet, community media and various mobile phone applications. However, its first appearance dates back to the early $20^{\text {th }}$ century.

From the analysis of questionnaire data provided by Hungarian ride-sharers and the routes and destinations of Oszkár, their most popular platform, it can be concluded that in Hungary the primary ride-sharers are young

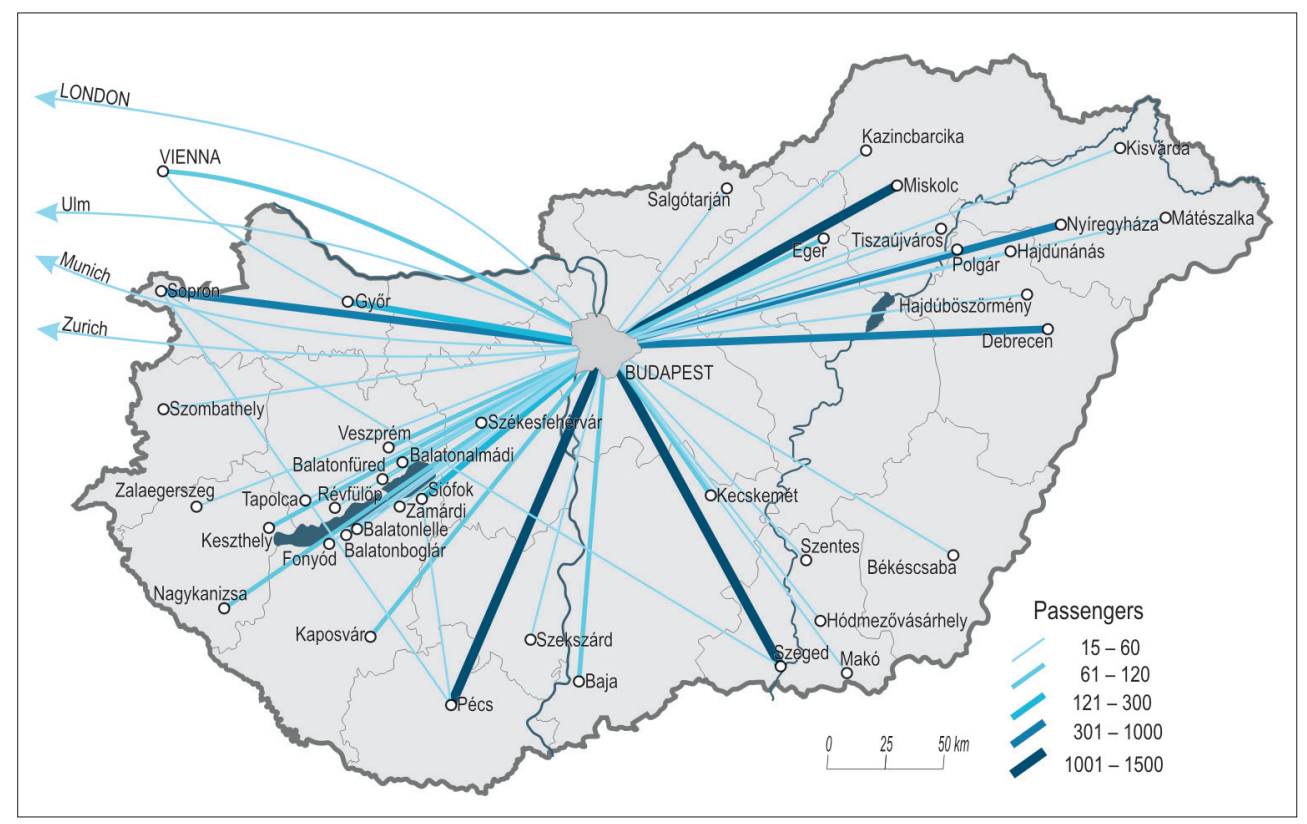

Fig. 7. Top 50 most popular ridesharing routes in a summer week (29 June-5 July). Source: Compiled by the authors based on Oszkár data. 


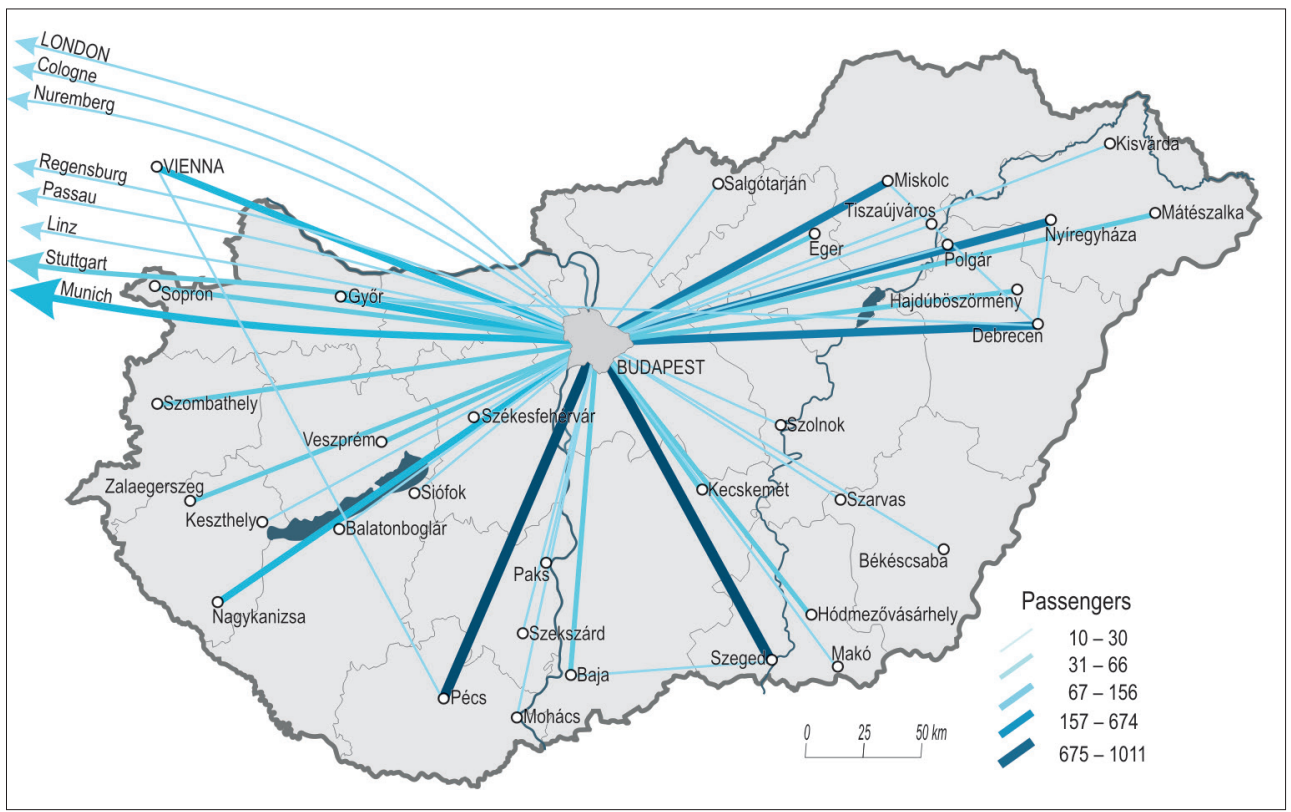

Fig. 8. Top 50 most popular ridesharing routes in a winter week (8-14, December). Source: Compiled by the authors based on Oszkár data

people in their late twenties, and, partly related to this, mostly those with higher levels of educations. Because the spreading of innovation is typically bound to settlement hierarchies and because of the critical mass, the absolute number of users is correlated with settlement size, but relative to population sizes, it is not Budapest but regional centres that yield the highest numbers of travellers.

Looking at the spatial effects, the ridesharing is also a popular type of mobility in some regions and settlements where a huge gap can be found between fixed public transportation schedules and good accessibility of motorways, and it significantly reduces travel time and rationalises costs. Ridesharing is used mostly for domestic routes, and the critical lower threshold is around $100 \mathrm{~km}$ under which this type of mobility is not typically used.

The price-sensitivity of most of Hungarian society plays an important role in the growth of ridesharing. The analysis of costs shows that it is a cheaper way to travel compared with the services of public transport companies (looking at full-price fares), thus the pos- sibility of saving on travel costs for drivers is an important variable, and is also a significant motivation for passengers, too.

The majority of journeys are occasional, meaning that although the advantages of ridesharing, such as flexibility and fluidity, are important, there are challenges related with this type of mobility including the issue of safety, which the ridesharing network tries to tackle through its evaluation system. The geographic limitations of sharing-based mobility include the absence of a critical mass, which prevents peripheral villages with an ageing population from becoming involved in this type of mobility and enjoying this bottom-up community-based form of travelling.

Along these lines we can establish that the emergence of Hungarian ridesharing follows the hierarchical model of innovation distribution, in which Budapest, dominating the Hungarian settlement system in almost all dimensions, is clearly prevalent. Hierarchical diffusion means that it spreads from the higher levels of settlements, to the lower ones in settlement hierarchy; metropolitan areas 
are, thus, followed by small towns and rural areas. The ridesharing system is used mostly for reaching the capital, typically from the regional centres that experience the greatest attraction from Budapest, and mostly by young people who are the most open to innovation but are in the early stages of their careers are therefore still sensitive enough to pricing, making them susceptible to looking for alternative solutions.

Due to the dominance of the capital, and because of the narrow Hungarian market, this innovation has not yet actually spread beyond regional centres. In fact, the new directions in this respect are leading across international borders to neighbouring countries and the UK. This application operating in the virtual world has not yet brought about a breakthrough in the offline space either, since as mentioned above, no alternative transportation routes have developed in the country, to contribute significantly to the restructuring of Hungary's transportation networks.

This new form of grassroots mobility is still in an initial stage in Hungary, demonstrating in itself several local peculiarities. Its complementarity is temporal rather than spatial, yet its developmental dynamics and directions are quite promising (e.g. festivals and seasonality), compared to many other new innovations (e.g. Uber) in shared economies. In our sof shared mobility users. It will be interesting to explore the causes of dominant one-way trips with Oszkár, to help explore now ridesharing is in its embryonic, complementary stage at the moment in Hungary.

Acknowledgement: The authors express their gratefulness for Oszkár, the largest ridesharing community in Hungary who supported their work effectively by providing the database on their routes and prices.

\section{REFERENCES}

BAndhi, F. and Ecкhardt, G.M. 2012. Access-based consumption: The case of car sharing. Journal of Consumer Research 39. (4): 881-898.

BELK, R. 2007. Why not share rather than own? The Annals of the American Academy of Political and Social Science 611. (1): 126-140.
BeLK, R. 2014. You are what you can access: Sharing and collaborative consumption online. Journal of Business Research 67. (8): 1595-1600.

Botsman, R. and Rogers, R. 2011. What's mine is yours: how collaborative consumption is changing the way we live. London, Collins.

Castells, M. 2000.The rise of the network society: The information age: Economy, society, and culture. $2^{\text {nd }}$ edition, Chichester, John Wiley \& Sons.

Chan, N.D. and Shaheen, S.A. 2012. Ridesharing in North America: Past, present, and future. Transport Reviews 32. (1): 93-112.

Christensen, C.M. 1997. The innovator's dilemma: when new technologies cause great firms to fail. Boston, Massachusetts, Harvard Business School Press.

Csonka, B. and Csiszár, Cs. 2016. Service Quality Analysis and Assessment Method for European Carsharing Systems. Periodica Polytechnica Transportation Engineering 44. (2): 80-88.

FERguson, E. 1997. The rise and fall of the American carpool: 1970-1990. Transportation 24. (4): 349-376.

Furuhata, M., Dessouky, M., Ordóňez, F., Brunet, M.E., WANG, X. and KoenIG, S. 2013. Ridesharing: The state-of-the-art and future directions. Transportation Research Part B: Methodological 57. 28-46.

Guttentag, D. 2015. Airbnb: disruptive innovation and the rise of an informal tourism accommodation sector. Current Issues in Tourism 18. (12): 1192-1217.

Gyürüs, M., Prácser, A. and Csiszár, Cs. 2008. Telematikai alapokon müködő car pooling rendszer (Carpooling system based on telematics). Városi Közlekedés 5. 258-266.

Hamari, J., SJöklint, M. and UkKonen, A. 2015. The sharing economy: Why people participate in collaborative consumption. Journal of the Association for Information Science and Technology 1. 1-13.

Morency, C. 2007. The ambivalence of ridesharing. Transportation 34. (2): 239-253.

Tibori, T. 2010. Vásárlásaink térben és időben (Our purchases in space and time). Kultúra és Közösség 14. (2): 61-88.

VAn Dijk, J. 2012. The network society. London, Sage Publications.

Van Outrive, T., Van de Vijver, E., Van Malderen, L., Jourquin, B., Thomas, I., Verhetsel, A. and Witlox, F. 2012. What determines carpooling to workplaces in Belgium: location, organisation, or promotion? Journal of Transport Geography 22. 77-86.

Zervas, G., Prosperpio, D. and Byers, J. 2015. The rise of the sharing economy: Estimating the impact of Airbnb on the hotel industry. Boston, Boston University School of Management Research Paper.

http://www.ksh.hu/nepszamlalas/tablak_teruleti_00 http://www.oszkar.com

http://skift.com/2015/02/28/airbnbs-new-1-billionfunding-would-value-it-at-20-billion/

http://www.slideshare.net/slideshow/embed_ code/31818007

www.uber.com 
